IRA-International Journal of Technology \& Engineering

ISSN 2455-4480; Vol.03, Issue 03 (2016)

Institute of Research Advances

http://research-advances.org/index.php/IRAJTE

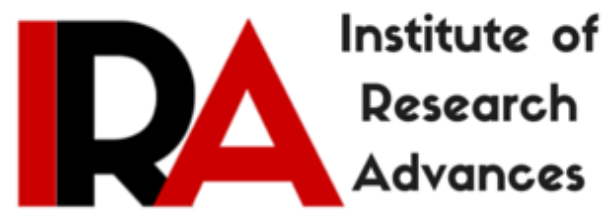

\title{
Assessment of Sea Water Intrusion in Muthupettai Block
}

\author{
${ }^{1}$ Miss.B.Pavithra, ${ }^{2}$ Mr.M.Renganathan \\ ${ }^{1} \mathrm{PG}$ student: Department of Civil Engineering, \\ ${ }^{2}$ Teaching Fellow: Department of Civil Engineering, \\ University College of Engineering-BIT Campus \\ Trichy, India.
}

DOI: http://dx.doi.org/10.21013/jte.v3.n3.p10

\section{How to cite this paper:}

Pavithra, B., \& Renganathan, M. (2016). Assessment of Sea Water Intrusion in Muthupettai Block. IRA-International Journal of Technology \& Engineering (ISSN 2455-4480), 3(3). doi:http://dx.doi.org/10.21013/jte.v3.n3.p10

\section{(C) Institute of Research Advances}

\section{(c) EY-NC}

This works is licensed under a Creative Commons Attribution-Non Commercial 4.0 International License subject to proper citation to the publication source of the work.

Disclaimer: The scholarly papers as reviewed and published by the Institute of Research Advances (IRA) are the views and opinions of their respective authors and are not the views or opinions of the IRA. The IRA disclaims of any harm or loss caused due to the published content to any party. 


ABSTRACT
Salt water intrusion into coastal aquifers is potentially a major problem in
the coastal region of Muthupettai block in Thiruthuraipoondi taluk (Thiruvarur
District, Tamil Nadu), hence in order to assess the vulnerability area, ground water
study should be done. By the water quality variations sea water mixing index is
assessed. Seawater mixing index is used to describe the vulnerability area and the
extension of intrusion over the study area. Thematic maps of factors influencing the
sea water intrusion were prepared and overlaid using Geographical Information
System (GIS). By the vulnerability mapping, the suitable area for the remediation
technique of sea water intrusion that should be practiced in the study area will be
decided. Rain water harvesting and artificial recharge techniques are more useful as
a tool in remediation of salt water intrusion. Estimation of surplus run-off is also very
important in planning artificial recharge schemes.

Keywords: Sea water intrusion, Aquifer vulnerability mapping, GIS, artificial recharge

\section{INTRODUCTION}

Saltwater intrusion into a fresh water bodies affecting water quality, vegetation and soil condition hence it is consider as a global issue. Contamination of this fresh water resource with sea water becomes threatening for water supply of coastal communities and their economic development. The most important causes for the degradation of fresh water in coastal aquifers are (i) its close proximity to sea water, and (ii) the significant water demand associated with coastal areas whereby ground water is often the main source of drinking water. This issue of saltwater intrusion is not new and has been addressed by many researches in the world. Various techniques can be adopted for resolving the problem. Field studies and numerical simulations are useful for planning the development activities in the coastal region over the coming years.

Groundwater recharge is the replenishment of an aquifer with water from the land surface. It is usually expressed as an average rate of $\mathrm{mm}$ of water per year, similar to precipitation. Artificial recharge is one of the remedial measures to minimize seawater intrusion in coastal aquifers. Modern tools such as Geographical information system (GIS) can be extensively used in groundwater investigations and analysis for mapping purposes, based on the compiled database. GIS is used to delineate areas favourable for recharge both in hard rock and sedimentary environs and to recommend simple recharge structures.

\section{METHODOLOGY}

Saltwater intrusion in the coastal region is a major issue related with the water management. The Studies on Remediation mechanisms of seawater intrusion through the implementation of artificial recharge system is carried out. Generally the groundwater samples from the different wells are collected and the physical and chemical parameters are analyzed. Sea water mixing index is calculated for the study area in order to find out the vulnerable area of sea water intrusion in the proposed area. Feasibility study of remediation technique is conducted by calculated the run off of the study area and suggest the suitable remediation technique with the help of hydrogeological, hydrometerological and hydrological studies. Artificial recharge method is a simple and effective method in the coastal areas for the effective recharge of the aquifer. 


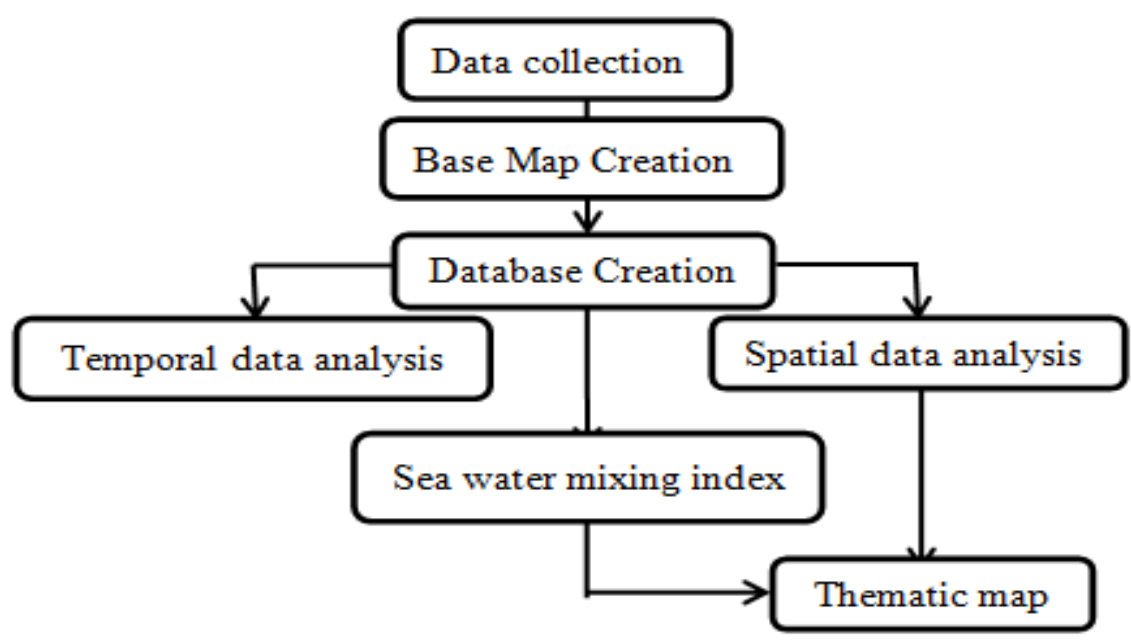

Figure 1 : Methodology flow chart

\section{STUDY AREA}

The study area is selected along the coastal zone of Thiruthuraipoondi taluk of Thiruvarur District which includes Koraiyar, Pamaniyar, Kandakurichan Channel, Kilaittangiar River, and Marakkakoraiyar River. The area forms part of Cauvery delta with gentle slope towards the Bay of Bengal. Muthupet mangrove forest is located at the southern end of the Cauvery delta, covering an area of approximately 13,500 ha of which only $4 \%$ is occupied by well-grown mangroves. At the tail end, they form a lagoon before meeting the sea. The zone is spread over an area of about $177 \mathrm{Km}^{2}$ and the Mullippallam creek covers an area of $11.4 \mathrm{Km}^{2}$. The study area lies between latitudes $10^{\circ} 16^{\prime} 00^{\prime} \mathrm{N}$ and $10^{\circ} 34^{\prime} 00^{\prime} \mathrm{N}$ and longitudes $79^{\circ} 30^{\prime} 00^{\prime \prime} \mathrm{E}$ and $79^{\circ} 37^{\prime} 30^{\prime \prime} \mathrm{E}$. The area is bordered on the East by Koraiyar and Kandaparichanar, on the west by Marakkakoraiyar, on the south by Bay of Bengal coast. 


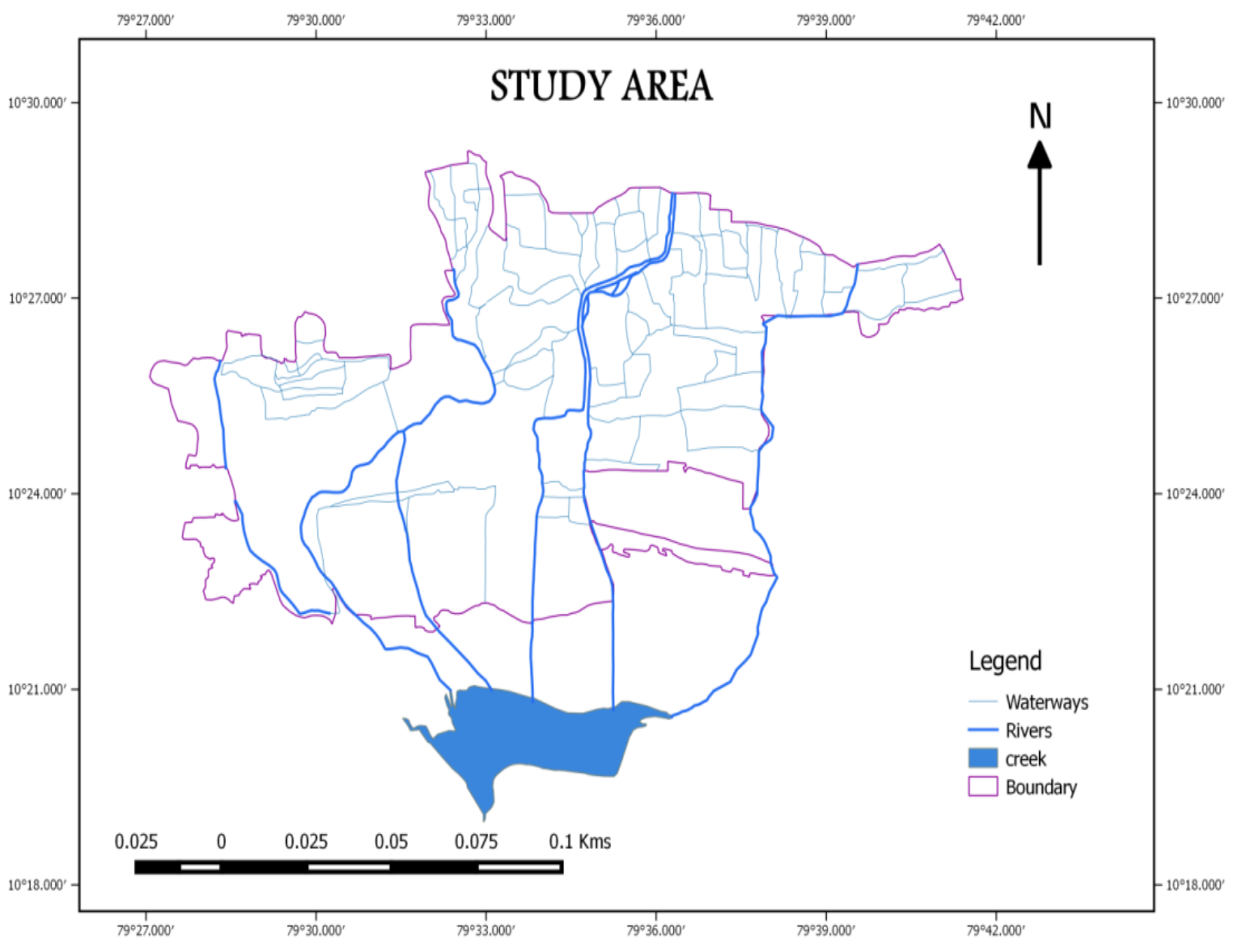

Figure 2 : Study area 


\section{DATA COLLECTION}

The secondary data (Water level and water quality data) was collected from Central Ground Water Board, Ministry of Water Resources, and State Ground and Surface Water Data Resources Organization, Govt of Tamil Nadu. The secondary data includes the rainfall data from 1985 to 2015 and water quality data from 20042014. The water quality data I categorized in respective locations and database for the temporal variation is analysed.

Study area has been delineated from the Topo sheets (No $44^{\text {th }}$ H7, H11) which is obtained from Survey of India. The base map is created in ArcGIS.

\section{WATER QUALITY VARIATIONS}

The water quality data collected from the CGWB is taken for the analysis comparing with the rainfall data. Graphs are drawn with parameters like TDS, EC concentration which are more responsible parameters for indicating the Seawater intrusion. The variation in the EC and TDS graph shows that the EC and TDS value is higher for Muthupet and Uppur when compared with the EC and TDS values of Sangandi from the fig 3 and 4 respectively.

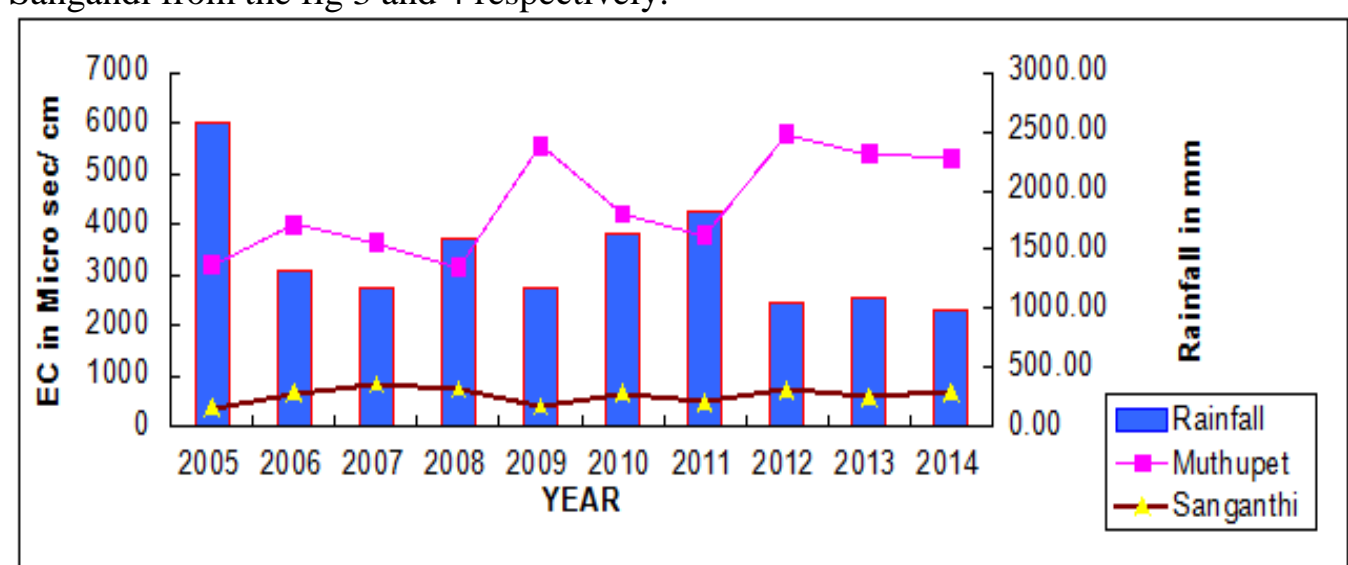

Figure 3 Variation of electrical conductivity from $2005-2014$

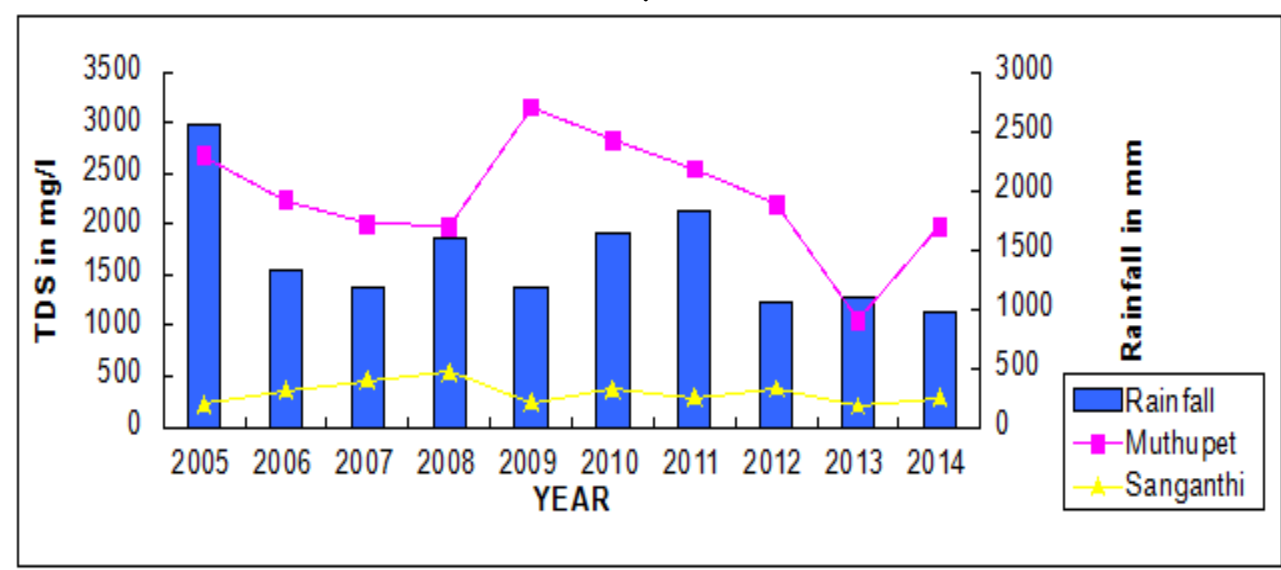

Figure 4 Variation of Total Dissolved solids from 2005-2014 


\section{SAMPLE COLLECTION}

The water samples are collected at various areas in the study field, with an equal interval of 2degree 30 minutes. The details of the sample location are given in the figure 3.5. Totally 16 samples were collected. These samples are collected in Polyethylene containers and brought to the laboratory within 24 hours for further testing procedures of samples and analysis of water quality parameters.

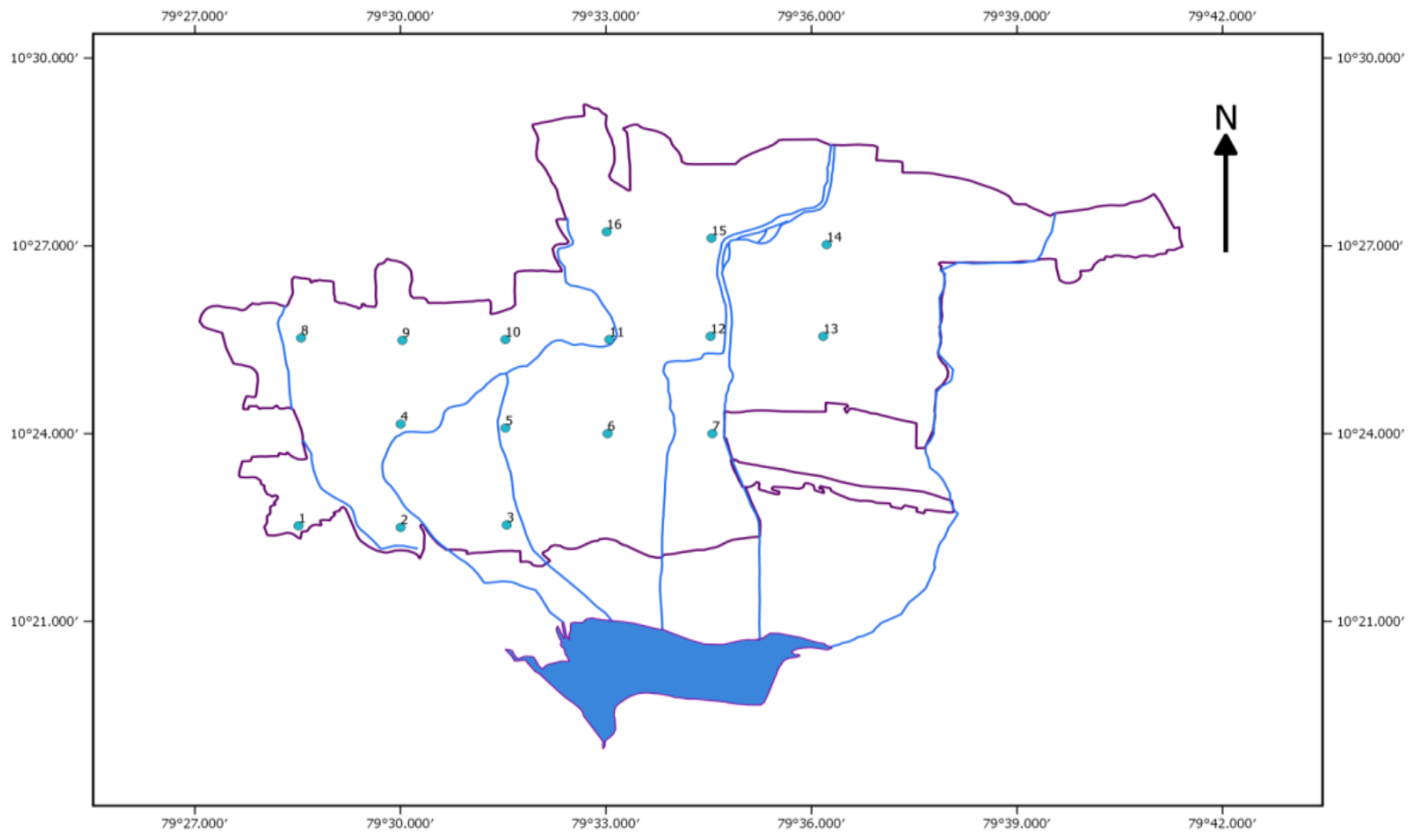

Figure 5 : Location of sample wells 


\begin{tabular}{|c|c|c|c|}
\hline \multirow{2}{*}{ Sample no } & Village & Sample no & Village \\
\hline 1 & M.K.Nagar & 9 & Uppur \\
\hline 2 & Pettai & 10 & Kovilur \\
\hline 3 & Jambuvanodai colony & 11 & Gopalasamudram \\
\hline 4 & Muthupettai & 12 & Palliyamodu \\
\hline 5 & Viranvayal & 13 & Idumbavanam \\
\hline 6 & Kaluvangadu & 14 & Kikkadau \\
\hline 7 & Mel vadiyakadu & 15 & Sangandi \\
\hline 8 & Pettavilamkottagam & 16 & Nachikulam \\
\hline
\end{tabular}

\section{RESULTS AND DISCUSSION}

a. Sea water mixing index The concentration of $\mathrm{Na}^{+}, \mathrm{Mg}^{+}, \mathrm{Cl}^{-}, \mathrm{SO}_{4}{ }^{2-}$ are used to calculate the sea water mixing index. It had been calculated using the following equation.

$$
\mathrm{SMI}=a \times \frac{C_{\mathrm{Na}}}{T_{\mathrm{Na}}}+b \times \frac{C_{\mathrm{Mg}}}{T_{\mathrm{Mg}}}+c \times \frac{C_{\mathrm{Cl}}}{T_{\mathrm{C}}}+d \times \frac{C_{50_{4}}}{T_{S 0_{4}}}
$$

Where, Constants a, b, c and denotes a relative proportion of $\mathrm{Na}+, \mathrm{Mg}+, \mathrm{Cl}-, \mathrm{SO} 42-$ respectively, there values are $(\mathrm{a}=0.31$, $\mathrm{b}=0.04, \mathrm{c}=0.57, \mathrm{~d}=0.08$ ), $\mathrm{T}$ is the regional threshold values and $\mathrm{C}$ is the calculated Concentration of groundwater samples.

\begin{tabular}{|l|l|l|l|l|l|l|l|}
\hline S.NO & \multicolumn{1}{|l|}{ VILLAGE } & SMI & $\begin{array}{c}\text { NATURE } \\
\text { OF } \\
\text { WATER }\end{array}$ & S.NO & VILLAGE & SMI & $\begin{array}{c}\text { NATUR } \\
\text { OF } \\
\text { WATER }\end{array}$ \\
\hline 1 & M.K.Nagar & 3.189 & SALINE & 9 & Uppur & 6.739 & SALINE \\
\hline 2 & Pettai & 2.604 & SALINE & 10 & Kovilur & 1.304 & SALINE \\
\hline 3 & $\begin{array}{l}\text { Jambuvanodai } \\
\text { colony }\end{array}$ & 3.667 & SALINE & 11 & Gopalasamudram & 1.507 & SALINE \\
\hline 4 & Muthupettai & 7.144 & SALINE & 12 & Palliyamodu & 0.818 & FRESH \\
\hline 5 & Viranvayal & 2.714 & SALINE & 13 & Idumbavanam & 0.805 & FRESH \\
\hline 6 & Kaluvangadu & 0.978 & FRESH & 14 & Kikkadau & 0.802 & FRESH \\
\hline 7 & Mel vadiyakadu & 0.762 & FRESH & 15 & Sangandi & 0.400 & FRESH \\
\hline 8 & Pettavilamkottagam & 1.190 & SALINE & 16 & Nachikulam & 0.583 & FRESH \\
\hline
\end{tabular}

\section{b. Spatial Variation maps}

The variations of the water quality for the study area from the 16 wells are studied using ArcGIS. The spatial variation of TDS, $\mathrm{Cl}$ and $\mathrm{EC}$ for the pre-monsoon and post monsoon seasons are shown. Because, statistical analysis proves that $\mathrm{EC}, \mathrm{Cl}$ and TDS are the best indicators of sea water intrusion. 


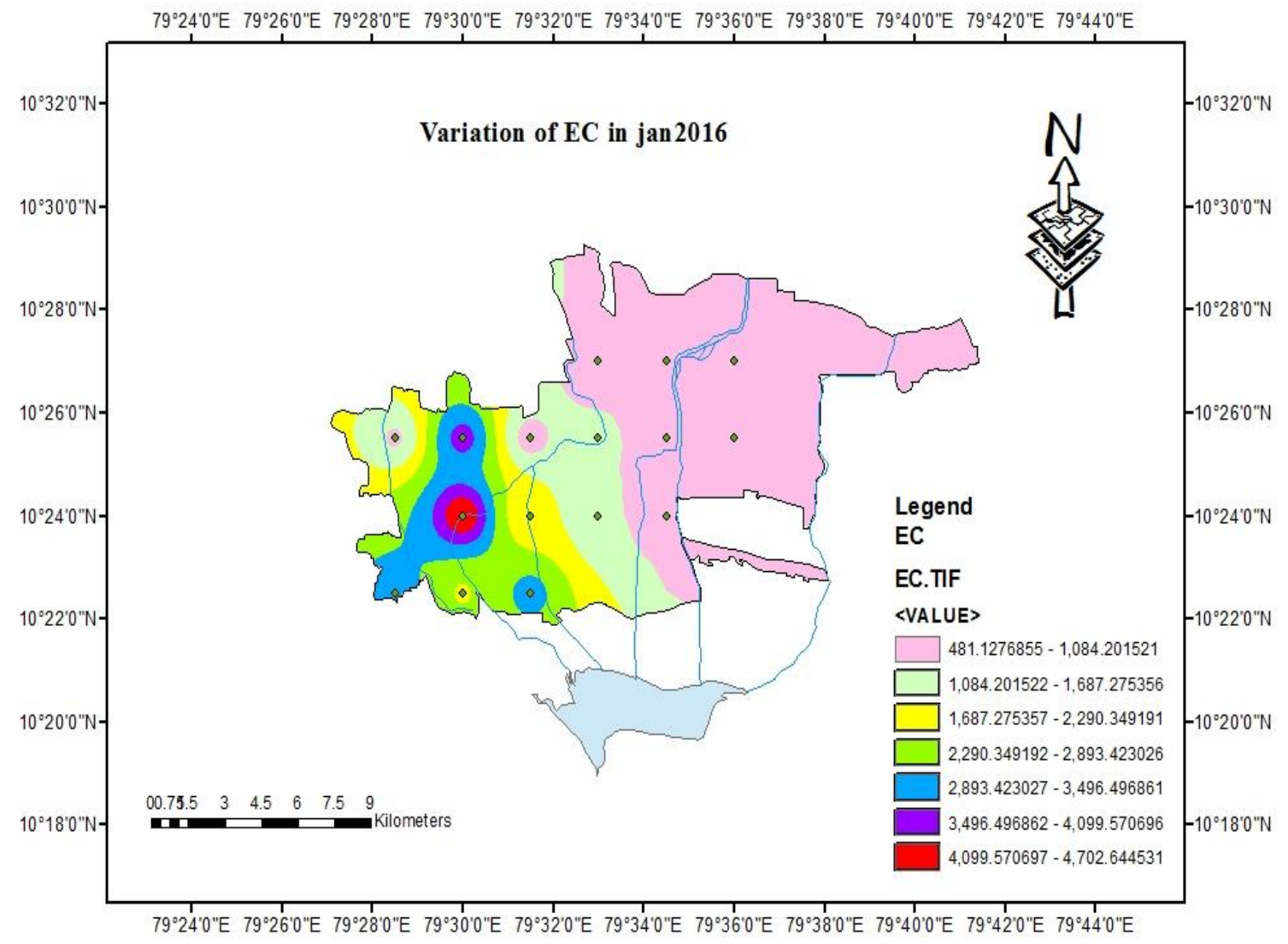

Figure 6 : spatial variation map of EC 


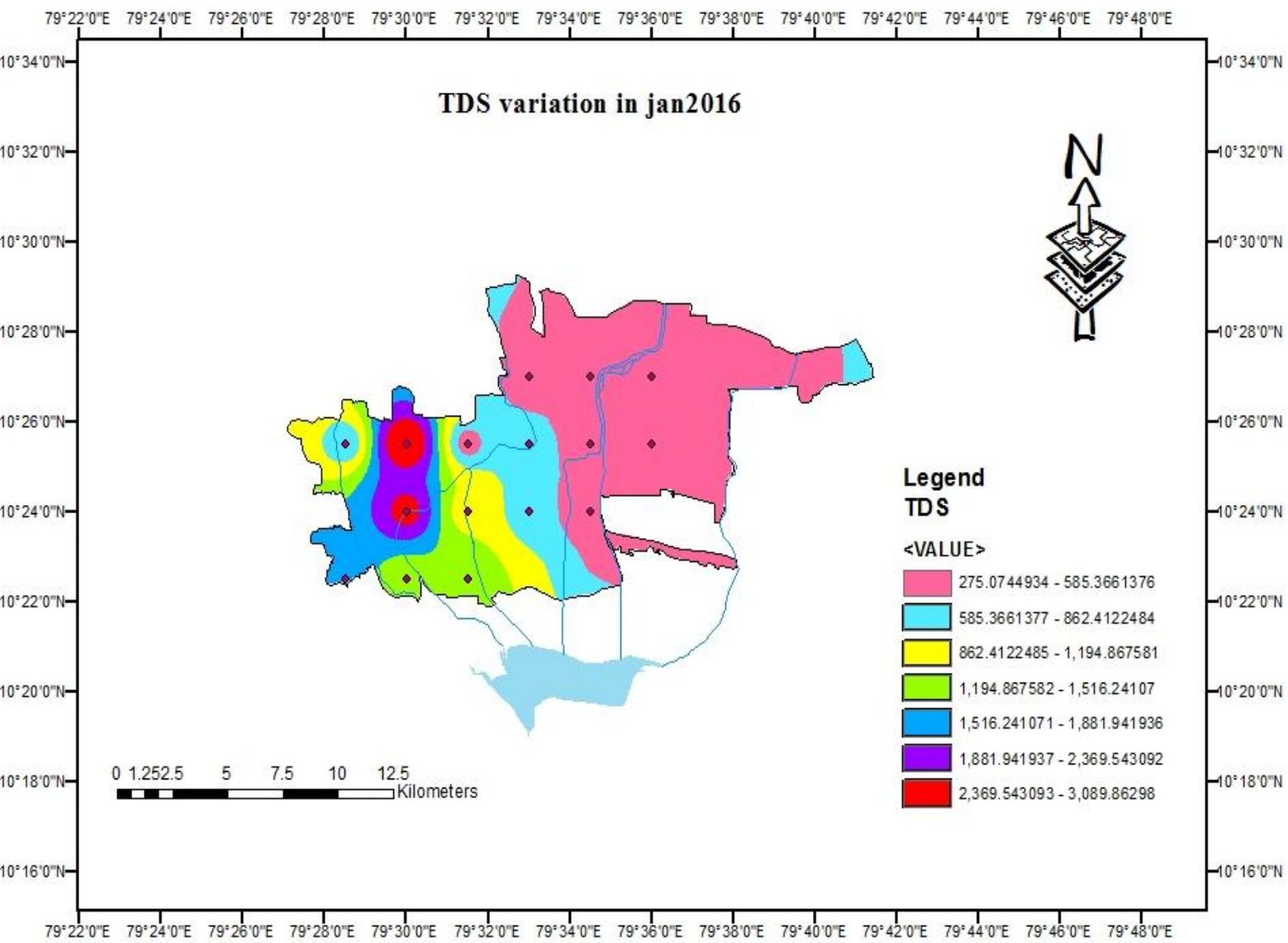

Figure 7 : Spatial variation map of TDS in the study area 


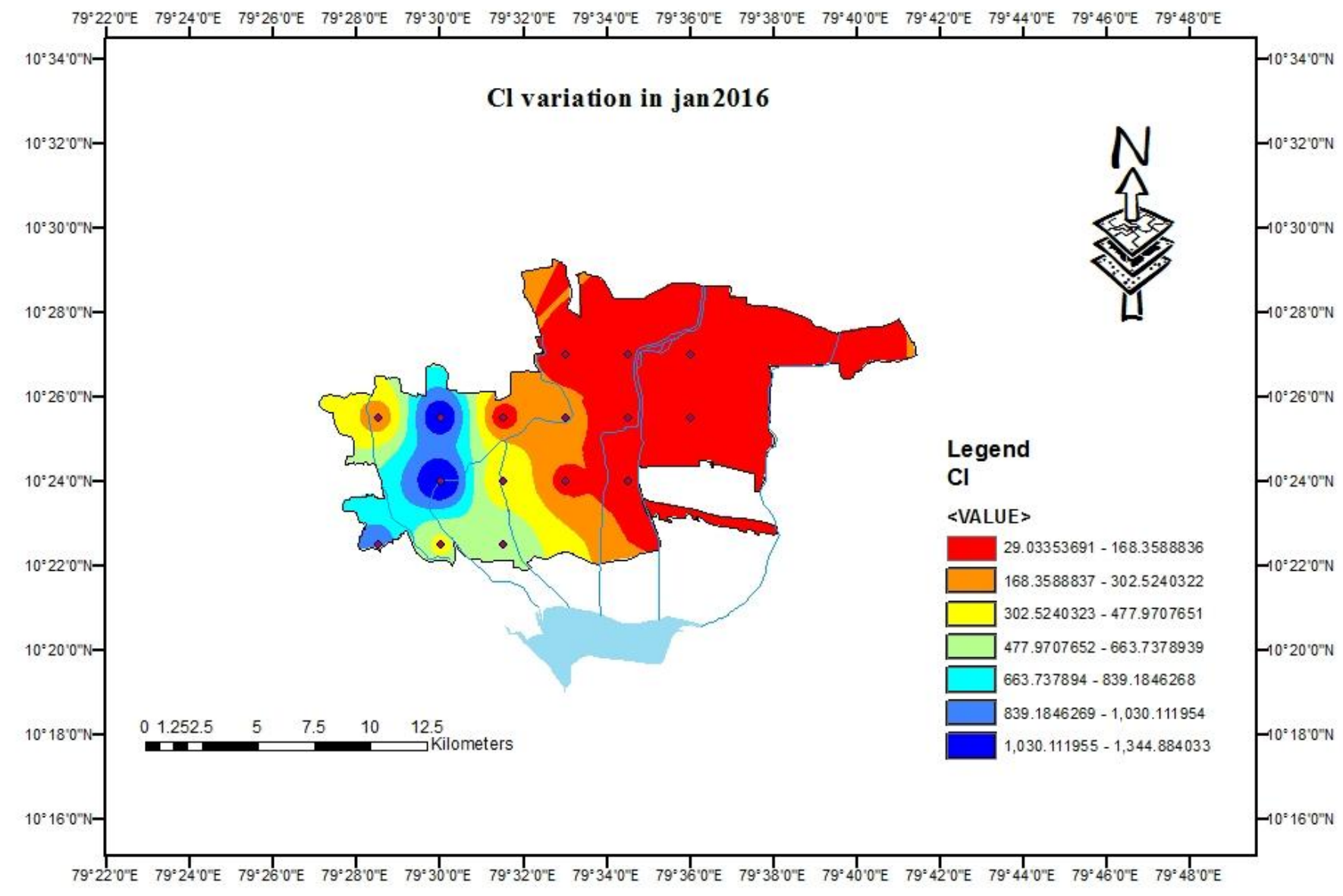

Figure 8 ; Spatial variation map of $\mathrm{Cl}$ in the study area 


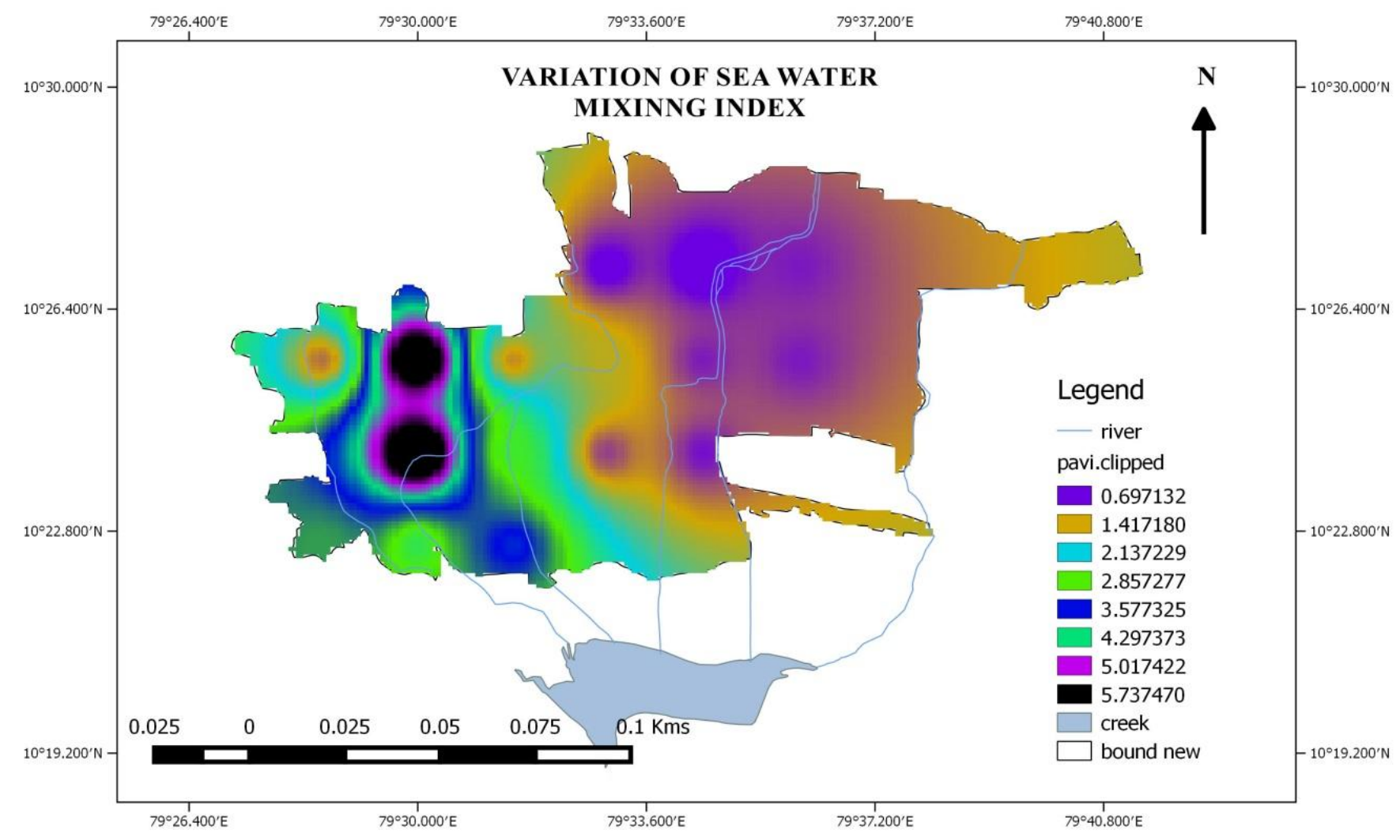

Figure 9 : variation of SMI in the study area 


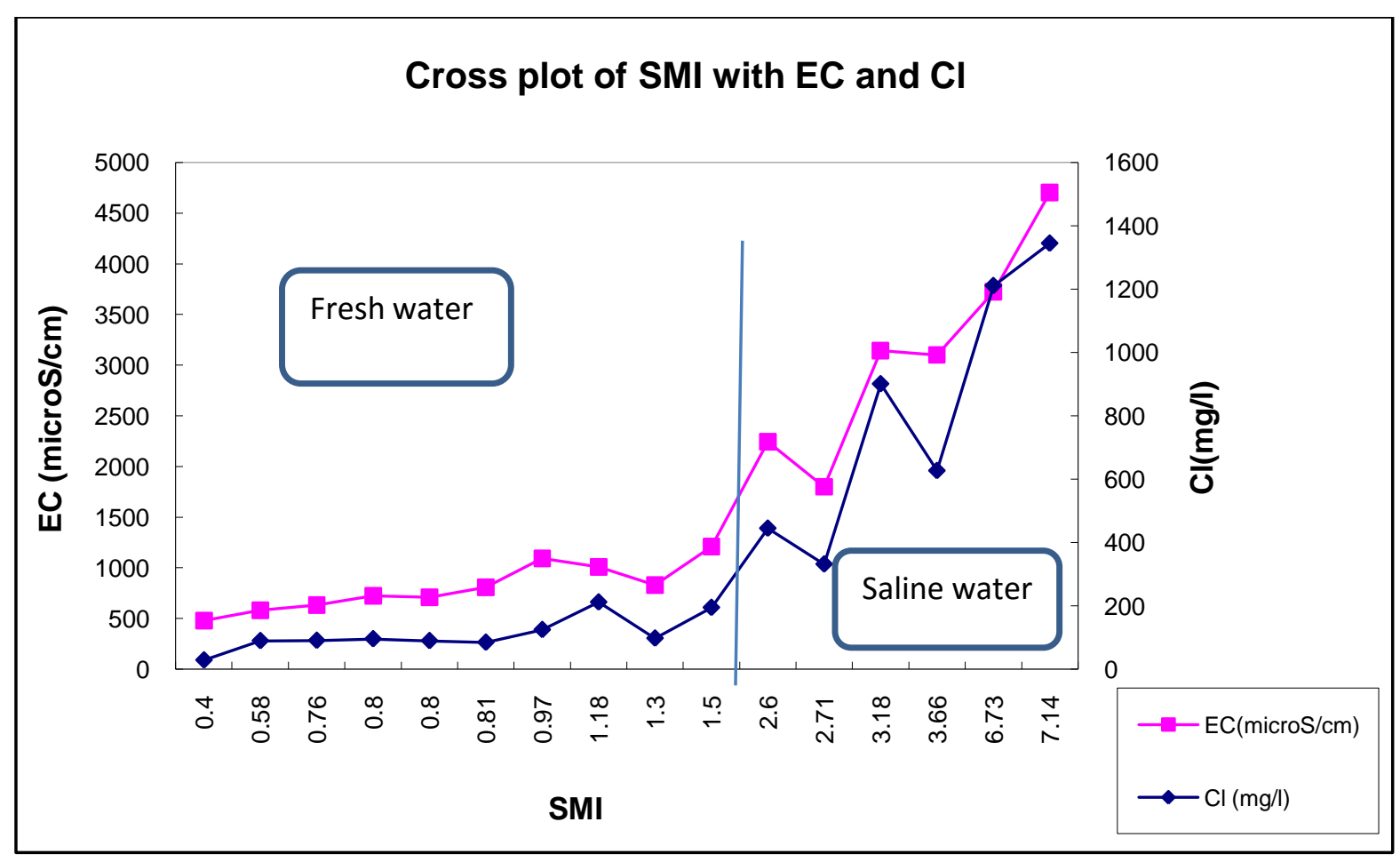

Figure 10 : Cross plot of SMI with EC and cl 


\section{CONCLUSION}

The sea water mixing index shows that most of the areas in the Muthupettai block are intruded with sea water. From the temporal and spatial analysis it is concluded that uppur village and Muthupettai town prone to higher vulnerability to sea water intrusion. Even both the areas have been similar in site characteristics; uppur village is selected for the construction of artificial recharge structure, because it has enough field area for the construction procedure when compared to Muthupettai.

\section{REFERENCES}

[1] A. Mahesha, S. H. Nagaraja. "Effect of Natural Recharge on Seawater Intrusion in Coastal Aquifers", Journal of Hydrology 174, PP. 211-220, 1996.

[2] A. Mahesha, Vyshali, Lathashri. U. A. and Moumitha. P. Studies on Saltwater Intrusion in Gurpur-Pavanje River Basin, Karnataka. Simulation of Saltwater Intrusion in the Coastal Aqifers of D.K. District, M. Tech. Thesis, PP. 126, 2006

[3] Adrian D. Werner, Mark Bakker, Vincent E.A. Post, Alexander Vandenbohede, Chunhui Lu, Behzad Ataie-Ashtiani, Craig T. Simmon, D.A. Barry. "Seawater Intrusion Processes, Investigation and Management: Recent Advances and Future Challenges", Advances in water resources 51, PP 3-26, 2013

[4] Amatya Kumar Bhattacharya. Artificial groundwater recharge with a special reference to India, IJRRAS 4(2) 2010

[5] Antonis D. Koussis, Katerina Mazi, Georgia Destouni. Analytical SinglePotential, Sharp-Interface Solutions for Regional Seawater Intrusion in Sloping Unconfined Coastal Aquifers, with Pumping and Recharge. Journal of Hydrology PP. 416-417, 2012.

[6] Jun Zhou, Xilai Zheng, Markus Flury, Guoqing Lin. Permeability changes during remediation of an aquifer affected by sea-water intrusion: A laboratory column study. Journals of Hydrology 376, PP. 557-566, 2009.

[7] López-Geta, Juan Antonio and Gómez-Gómez, Juan de Dios, The Problem of Saltwater Intrusion into Coastal Aquifers, their Protection and Remediation. International Symposium on Groundwater Sustainability (ISGWAS) PP. 211223, 2004.

[8] R. Rangarajan , N. C. Mondal , V. S. Singh and S. V. Singh, Estimation of Natural Recharge and its Relation with Aquifer Parameters in and around Tuticorin town, Tamil Nadu, India. National Geophysical Research Institute, Current Science Vol. 97, NO. 2, 25 July 2009.

[9] Rama Rao, D., Satyanarayana , T. and Machiraju, P.V.S, Assessment of Groundwater Quality for Application in Kakinada Coast. Der Chemica Sinica Vol. 3(1), PP. 287-291, 2012.

[10] V. Lenin Kalyana Sundaram, G. Dinesh (2008), Vulnerability assessment of seawater intrusion and effect of artificial recharge in Pondicherry coastal region using GIS , Hydrological Engineering 